\title{
Orexin (Hypocretin) Neurons Contain Dynorphin
}

\author{
Thomas C. Chou, ${ }^{1}$ Charlotte E. Lee, ${ }^{2}$ J. Lu, ${ }^{3}$ Joel K. Elmquist, ${ }^{2}$ Junko Hara, ${ }^{5}$ Jon T. Willie, ${ }^{4}$ \\ Carsten T. Beuckmann, ${ }^{4}$ Richard M. Chemelli, ${ }^{4}$ Takeshi Sakurai, ${ }^{5}$ Masashi Yanagisawa, ${ }^{4}$ Clifford B. Saper, ${ }^{1,3}$ \\ and Thomas E. Scammell ${ }^{3}$
}

\begin{abstract}
${ }^{1}$ Department of Neurobiology and Program in Neuroscience, Harvard Medical School, Boston, Massachusetts 02115 , Departments of ${ }^{2}$ Endocrinology and ${ }^{3}$ Neurology, Beth Israel Deaconess Medical Center, Boston, Massachusetts 02115 , 4 Howard Hughes Medical Institute and Department of Molecular Genetics, University of Texas Southwestern Medical Center at Dallas, Dallas, Texas 75390, and ${ }^{5}$ Department of Pharmacology, Institute of Basic Medical Sciences, University of Tsukuba, Tsukuba, Ibaraki 305-8575, Japan
\end{abstract}

Orexins (also called hypocretins) are peptide neurotransmitters expressed in neurons of the lateral hypothalamic area (LHA). Mice lacking the orexin peptides develop narcolepsy-like symptoms, whereas mice with a selective loss of the orexin neurons develop hypophagia and severe obesity in addition to the narcolepsy phenotype. These different phenotypes suggest that orexin neurons may contain neurotransmitters besides orexin that regulate feeding and energy balance. Dynorphin neurons are common in the LHA, and dynorphin has been shown to influence feeding; hence, we studied whether dynorphin and orexin are colocalized. In rats, double-label in situ hybridization revealed that nearly all (94\%) neurons expressing prepro-orexin mRNA also expressed prodynorphin mRNA. The converse was also true: $96 \%$ of neurons in the LHA containing

The neuropeptides orexin-A and orexin-B (also called hypocretin-1 and -2) are expressed in neurons of the lateral hypothalamic area (LHA), with a few orexin cells extending into the dorsomedial hypothalamic nucleus (DMH). Orexins may play a major role in regulating arousal, and lack of the orexin peptides or receptors is associated with symptoms of narcolepsy in mice (Chemelli et al., 1999), dogs (Lin et al., 1999), and humans (Nishino et al., 2000; Peyron et al., 2000; Thannickal et al., 2000). Orexin may not be the only functionally important neurotransmitter in these neurons: transgenic mice in which the orexin neurons are selectively destroyed develop not only narcolepsy, but also hypophagia and marked obesity (Hara et al., 2001), deficits only mildly evident in mice lacking the orexin peptides.

Although LHA neurons express a variety of neurotransmitters, few have been identified within the orexin neurons. Orexin does not colocalize with melanin-concentrating hormone, cocaine and amphetamine-related transcript, or nitric oxide synthase (Peyron et al., 1998; Cutler et al., 2001; Elias et al., 2001). The neuropeptide galanin is found in some orexin neurons, but many orexin

\footnotetext{
Received May 8, 2001; revised July 9, 2001; accepted July 9, 2001.

This work was supported by United States Public Health Service Grants MH62589, MH01507, and HL60292. Courtney Sears, Minh Ha, and Quan Ha provided expert technical assistance. M.Y. is an Investigator and C.T.B. is an Associate of the Howard Hughes Medical Institute. J.T.W. is a joint fellow of the Medical Scientist Training Program and the Department of Cell and Molecular Biology of University of Texas Southwestern.

Correspondence should be addressed to Dr. Thomas E. Scammell, Department of Neurology, Beth Israel Deaconess Medical Center, 77 Avenue Louis Pasteur, Boston, MA 02115. E-mail: tscammel@caregroup.harvard.edu.

Copyright (C) 2001 Society for Neuroscience 0270-6474/01/210001-06\$15.00/0
}

prodynorphin mRNA also expressed prepro-orexin mRNA. Double-label immunohistochemistry confirmed that orexin- $A$ and dynorphin-A peptides were highly colocalized in the LHA. Wild-type mice and orexin knock-out mice showed abundant prodynorphin mRNA-expressing neurons in the LHA, but orexin/ataxin-3 mice with a selective loss of the orexin neurons completely lacked prodynorphin mRNA in this area, further confirming that within the LHA, dynorphin expression is restricted to the orexin neurons. These findings suggest that dynorphin-A may play an important role in the function of the orexin neurons.

Key words: orexin; hypocretin; dynorphin; narcolepsy; obesity; feeding

neurons lack galanin (Hakansson et al., 1999). Orexin terminals innervating the tuberomammillary nucleus contain glutamate (F. Torrealba and C. B. Saper, personal communication), but orexin terminals in other areas have not been examined. Finally, dynorphin is expressed in many LHA neurons and has been implicated in the regulation of feeding (Gosnell et al., 1986), but its colocalization with orexin has not been directly examined.

To determine if orexin neurons contain dynorphin, we performed double-label in situ hybridization for prepro-orexin and prodynorphin mRNA. To confirm colocalization of the respective neuropeptides, we also performed double-label immunohistochemistry for orexin-A and dynorphin-A. Finally, we examined the colocalization of orexin and dynorphin in wild-type mice, in orexin knock-out mice, and in orexin/ataxin-3 mice that have a selective loss of orexin neurons.

This article is published in The Journal of Neuroscience, Rapid Communications Section, which publishes brief, peerreviewed papers online, not in print. Rapid Communications are posted online approximately one month earlier than they would appear if printed. They are listed in the Table of Contents of the next open issue of JNeurosci. Cite this article as: JNeurosci, 2001, 21:RC168 (1-6). The publication date is the date of posting online at www.jneurosci.org.

http://www.jneurosci.org/cgi/content/full/5644 


\section{MATERIALS AND METHODS}

Animals and tissue. All work was approved by the Animal Care and Use Committees of Harvard Medical School and University of Texas Southwestern Medical Center. Experiments used Sprague Dawley rats, 275300 gm (Harlan Sprague Dawley, Indianapolis, IN), C57BL/6 mice (Harlan), orexin knock-out mice, orexin/ataxin-3 transgenic mice, or the wild-type littermates of these mice. Orexin knock-outs and littermates were 16 weeks old, whereas orexin/ataxin-3 mice and littermates were 38-42 weeks old. Orexin knock-out mice and wild-type littermates were genetically similar to those previously described $(50 \% \mathrm{C} 57 \mathrm{BL} / 6,50 \%$ 129SvEv) (Chemelli et al., 1999). The orexin/ataxin-3 mice contain a transgene in which the human orexin promoter drives expression of a CAG-elongated form of ataxin-3 protein that results in the gradual and selective loss of orexin neurons by early adulthood (Hara et al., 2001). By 12 weeks of age, no orexin peptide or mRNA can be detected in the brains of these mice. The background strain of the orexin/ataxin-3 mice was $75 \%$ C57BL6 and 25\% DBA1.

Animals were transcardially perfused with $4 \%$ paraformaldehyde, and brains were removed and equilibrated overnight in PBS with $20 \%$ sucrose in diethylpyrocarbonate-treated water. Brains were sectioned on a freezing microtome into five series of $30 \mu \mathrm{m}$ sections (three series for mice). Rats used for double-label immunohistochemistry received the axonal transport blocker colchicine ( $1.5 \%$ in $12 \mu$ l of saline i.v.; Sigma) $24-48$ hours before killing to reveal dynorphin immunoreactivity within neuronal cell bodies.

Riboprobes and hybridization buffer for in situ hybridization. pSP64 plasmid containing bases 270-1988 of the rat prodynorphin cDNA sequence (Civelli et al., 1985) (a kind gift from A. Watts, University of Southern California) was linearized with EcoRI and transcribed with SP6 polymerase to produce antisense mRNA riboprobes for use on rat tissue. pSP65 plasmid containing the same insert in the opposite direction was used to produce sense riboprobes by linearizing with Pst I and transcribing with SP6 polymerase. The prodynorphin riboprobe used for in situ hybridization on mouse tissue was constructed from a 446 bp fragment of an expressed sequence tag (GenBank accession number AU066590) containing bases 293-738 of the prodynorphin coding region (Josefsen et al., 1998). This fragment was amplified using the polymerase chain reaction (left primer, TGCAGTGAGGATTCAGGATG; right primer, CGGAACTCCTCTTGGGGTAT) and inserted into the pCR4TOPO plasmid (Invitrogen, San Diego, CA). This plasmid was linearized with NotI or PstI and transcribed with T3 or T7 polymerase to produce antisense or sense riboprobes, respectively.

The prepro-orexin riboprobe was generated from a Bluescript II $\mathrm{SK}(+)$ plasmid containing bases $97-384$ of the rat prepro-orexin cDNA sequence as previously described (Sakurai et al., 1998). Across this fragment, the rat and mouse cDNA sequences are 98\% homologous [Basic Local Alignment Search Tool (BLAST), National Institutes of Health], making this probe suitable for hybridization in both species. This plasmid was linearized with Bam HI and transcribed with $\mathrm{T} 7$ to produce antisense probe.

All probes were transcribed using nucleotides labeled with either ${ }^{35} \mathrm{~S}$ or digoxigenin and were diluted in hybridization buffer as previously described (Simmons et al., 1989; Kerner et al., 1998). Radiolabeled riboprobes were diluted to give $3 \times 10^{6}$ counts per $125 \mu \mathrm{l}$, whereas digoxigenin-labeled probes were diluted 1:100 in hybridization buffer.

Double-label in situ hybridization. Double-label in situ hybridization procedures were adapted from previously described methods (Simmons et al., 1989; Kerner et al., 1998; Elias et al., 2001). Slight modifications included replacement of the proteinase $\mathrm{K}$ pretreatment with microwave pretreatment of tissue for $10 \mathrm{~min}$ on high heat in citrate buffer, $\mathrm{pH} \mathrm{6.0,}$ as previously described (Marcus et al., 2001). Sections were incubated in hybridization buffer containing both orexin and dynorphin riboprobes for $12-16 \mathrm{hr}$ at $56^{\circ} \mathrm{C}$, followed by overnight incubation in alkalinephosphatase-conjugated sheep anti-digoxigenin antibodies (1:5000 dilution; Roche Products, Hertforshire, UK). Blue-purple reaction product was visualized by incubation for $4-8 \mathrm{hr}$ in nitroblue tetrazolium chloride (Roche) (Kerner et al., 1998). Slides were coated with a thin layer of parlodion (Sigma) to prevent chemical interactions between the alkaline phosphatase reaction product and photographic emulsion-developer. Slides were dipped in NTB2 photographic emulsion (International Biotechnologies, New Haven, CT), stored in the dark for $4 \mathrm{~d}$, and developed with D-19 developer (Eastman Kodak, Rochester, NY) for 2 min.

No specific labeling was seen when the antisense riboprobes were omitted or replaced with sense probes.

Double-label immunohistochemistry. Free-floating sections were incu- bated overnight at room temperature in rabbit anti-dynorphin $\mathrm{A}$ antiserum (1:200 dilution; Peninsula Laboratories, Belmont, CA), followed by incubation for $1 \mathrm{hr}$ in biotinylated donkey anti-rabbit IgG (1:500; Jackson ImmunoResearch, West Grove, PA), and $30 \mathrm{~min}$ in cyanine3conjugated streptavidin (1:1000; Jackson ImmunoResearch). Sections were then incubated in rabbit anti-orexin A antiserum overnight (1:5000) (Estabrooke et al., 2001), in biotinylated donkey anti-rabbit IgG for 30 min (1:1000; Jackson), and in streptavidin conjugated to the green fluorescent dye Alexafluor-488 (1:1000; Molecular Probes, Eugene, OR) for $10 \mathrm{~min}$.

Because both primary antisera were raised in rabbits, several steps were taken to minimize antibody cross-reactivity. We used the same lot of secondary antiserum for both stains; thus, the first application of the secondary antiserum saturated binding sites on the dynorphin primary, blocking the majority of subsequent binding to these sites during the second immunostain for orexin. To further reduce potentially crossreacting binding sites, the more weakly expressed antigen (in this case dynorphin) was always stained first.

Cell counts. Alkaline phosphatase-labeled neurons were counted using a Leitz microscope with bright-field illumination, whereas silver grains overlying ${ }^{35} \mathrm{~S}$-labeled neurons were counted under dark-field illumination. Neurons expressing $>3 \times$ as many silver grains as background were considered radiolabeled. Orexin and dynorphin neurons were counted in the LHA in six to eight coronal sections starting just caudal to the paraventricular hypothalamic nucleus and ending at the premammillary area. These sections included the entire orexin field, with no orexin neurons occurring outside of these sections. The LHA was defined broadly to include all hypothalamic regions lateral to the $\mathrm{DMH}$ and ventromedial hypothalamic nuclei, with the exception of the supraoptic nucleus. We also counted orexin and dynorphin cells within the DMH, except for the pars compacta of the DMH, which contains many dynorphin-expressing neurons that are morphologically and cytoarchitecturally distinct from dynorphin neurons in the LHA. Nuclear landmarks were clearly identifiable under dark-field illumination.

Double-labeled immunoreactive cells were counted under fluorescent episcopic illumination. To avoid false detection of double-labeled neurons caused by antibody cross-reactivity, we only counted neurons in which immunoreactivities for both dynorphin (red immunofluorescence) and orexin (green immunofluorescence) were relatively intense. In particular, neurons showing strong dynorphin immunoreactivity, but comparatively weak orexin immunoreactivity (which was stained second, and therefore most likely to be artifactual) were conservatively interpreted as single-labeled dynorphin-immunoreactive neurons. No double-labeled neurons were evident when either primary antiserum was omitted.

\section{RESULTS}

\section{Dynorphin and orexin colocalization in the rat}

Hypothalamic sections from four rat brains were processed for double-label in situ hybridization for prepro-orexin and prodynorphin. Almost all neurons expressing prepro-orexin mRNA ( $94 \pm 2 \%$ SEM) also expressed prodynorphin mRNA (Fig. $1 A-$ $D)$. In the LHA and DMH (excluding the pars compacta), the converse was also true: almost all prodynorphin mRNAexpressing neurons $(96 \pm 1 \%)$ also expressed prepro-orexin mRNA. This high degree of colocalization was maintained throughout the entire extent of the orexin cell population. Many neurons expressing prodynorphin were seen in adjacent hypothalamic areas, such as the supraoptic nucleus, the paraventricular hypothalamic nucleus, the ventromedial hypothalamic nucleus, and the pars compacta subregion of the $\mathrm{DMH}$, but these neurons never expressed prepro-orexin mRNA (Fig. 1E,F).

To confirm whether dynorphin and orexin peptides were colocalized, three brains from colchicine-treated rats were processed for double-label immunohistochemistry. The distributions of orexin-A and dynorphin-A-immunoreactive neurons were almost identical to the mRNA distributions seen with in situ hybridization. Nearly all orexin-immunoreactive neurons $(94 \pm 2 \%)$ were dynorphin-A-immunoreactive (Fig. 2). Conversely, within the LHA and DMH (excluding the pars compacta of the DMH) almost all dynorphin-A-immunoreactive neurons $(97 \pm 1 \%)$ were 

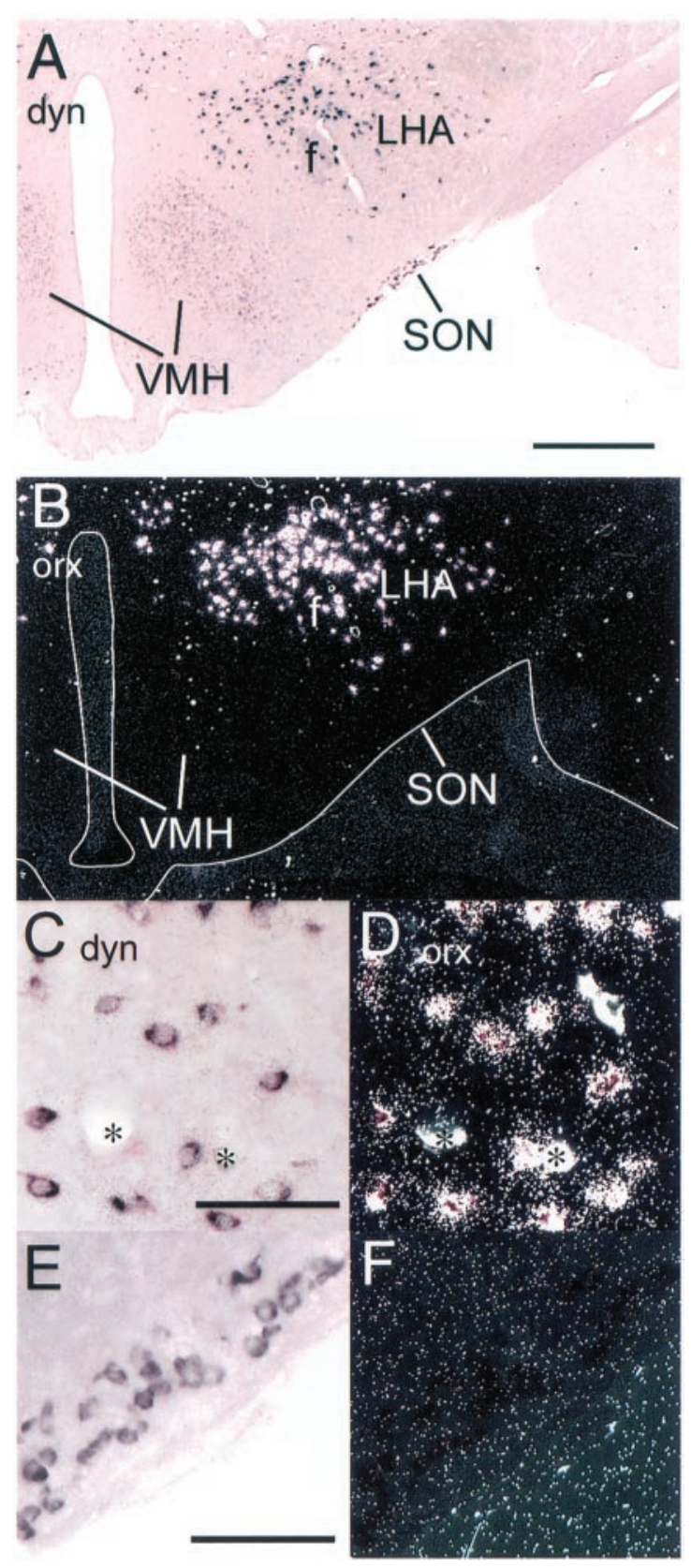

Figure 1. Double-label in situ hybridization for prodynorphin and prepro-orexin mRNA in normal rat hypothalamus. A, Purple digoxigenin reaction product indicates many prodynorphin-expressing neurons in the lateral hypothalamic area $(L H A)$ above the fornix $(f)$, in the supraoptic nucleus $(S O N)$, and in the ventromedial hypothalamic nucleus $(V M H) . B$, A dark-field view of the same section shows bright silver grains indicating prepro-orexin mRNA expression only in the LHA. Higher magnification views of the LHA in bright-field $(C)$ and dark-field $(D)$ show prodynorphin and prepro-orexin labeling, respectively. Every labeled cell is double-labeled. Bright artifacts visible in dark-field (asterisks) are attributable to air trapped in blood vessels under parlodion coating. Highpower views of the SON show that many neurons hybridize prodynorphin mRNA $(E)$, whereas no prepro-orexin expression is seen $(F)$. Scale bars: $A, B, 200 \mu \mathrm{m} ; C-F, 100 \mu \mathrm{m}$.

orexin-A-immunoreactive. This high degree of colocalization was evident throughout the orexin field.

\section{Colocalization of dynorphin and orexin in mice}

Wild-type mice had a similar distribution of neurons containing prepro-orexin and dynorphin mRNAs as seen in rats. In four normal C57BL/6 mice, prodynorphin mRNA was present in nearly all prepro-orexin-containing neurons, whereas nearby regions such as the supraoptic nucleus and pars compacta of the $\mathrm{DMH}$ contained many prodynorphin-expressing neurons that never expressed prepro-orexin mRNA. In three orexin knock-out mice, labeling for prepro-orexin was completely absent, but the distribution and number of prodynorphin-containing neurons in the LHA was the same as seen in their wild-type littermates (Fig. 3 ). In three orexin/ataxin-3 mice, both prepro-orexin and prodynorphin labeling were completely absent from the LHA, whereas the number of prodynorphin-containing cells in adjacent regions was similar to that seen in their wild-type littermates.

\section{DISCUSSION}

We found that nearly all orexin neurons contain dynorphin at both the mRNA and protein levels in rats, and that in the LHA, dynorphin is only expressed in the orexin neurons. Wild-type mice showed a similarly high degree of colocalization of prodynorphin and prepro-orexin mRNA. By comparison, orexin knock-out mice lacked prepro-orexin mRNA but still had abundant prodynorphin mRNA-expressing neurons in the LHA, whereas orexin/ataxin-3 mice lacked both prepro-orexin and prodynorphin mRNA in the LHA.

\section{Methodological considerations}

We minimized several common sources of artifactual doublelabeling. To avoid cross-hybridization between riboprobes, we used riboprobes of at least several hundred bases in length that have no significant similarities to each other or to other known rat or mouse genes (verified using BLAST). To limit chemical interactions between the alkaline phosphatase immunohistochemical reaction product and overlying photographic emulsion, we coated the tissue with a thin layer of parlodion before applying the emulsion. The effectiveness of these procedures was shown by the presence of some single-labeled neurons of both types in all double-label in situ hybridizations using wild-type animals and by the lack of double-labeling when either riboprobe was omitted. Finally, the use of orexin-A and dynorphin-A primary antisera that were both made in rabbits raised the possibility of artifactual double-labeling caused by antibody cross-reactivity. However, histochemical controls and stringent counting criteria eliminated artifactual double-labeling, as seen in trials in which one primary antibody was omitted.

The current findings corroborate previous observations showing that dynorphin immunoreactivity in the LHA colocalizes with immunoreactivity for a particular antiserum raised against prolactin (Griffond et al., 1993), although prolactin immunoreactivity in the LHA is not detected by monoclonal antibodies to prolactin (Harlan and Scammell, 1991). The prolactin antiserum used by Griffond et al. (1993) was later shown to recognize a fragment of the prepro-orexin peptide (Risold et al., 1999), indirectly suggesting that dynorphin in LHA neurons might colocalize with orexin. However, the polyclonal antiserum used by Griffond et al. (1993) might have recognized additional antigens as well. By using double-label in situ hybridization and transgenic animals, we avoided problems with antigen cross-reactivity.

\section{Functional implications}

Although orexin is produced mainly within neurons of the LHA, dynorphin neurons are found in many other hypothalamic regions, as well as in the cortex, striatum, and brainstem. Dynorphin probably mediates many functions in the brain, but within the 
Figure 2. Double-label immunohistochemistry for orexin-A and dynorphin-A in rats. $A$, Abundant red dynorphin immunofluorescence is visible in the SON and in the LHA above the fornix $(f)$. $B$, In the same section, green immunofluorescence for orexin only appears in the LHA. $C$, When orexin and dynorphin signals are superimposed, many doublelabeled neurons (yellow) appear in the LHA, whereas SON neurons are only single-labeled for dynorphin. $D$, A higher magnification view of the perifornical region shows that almost all LHA neurons are double-labeled, as indicated by intense yellow color. A few cells appear reddish yellow or greenish yellow because relative expression levels of the two peptides vary between neurons. Scale bars: $A-C, 400 \mu \mathrm{m} ; D$, $100 \mu \mathrm{m}$.
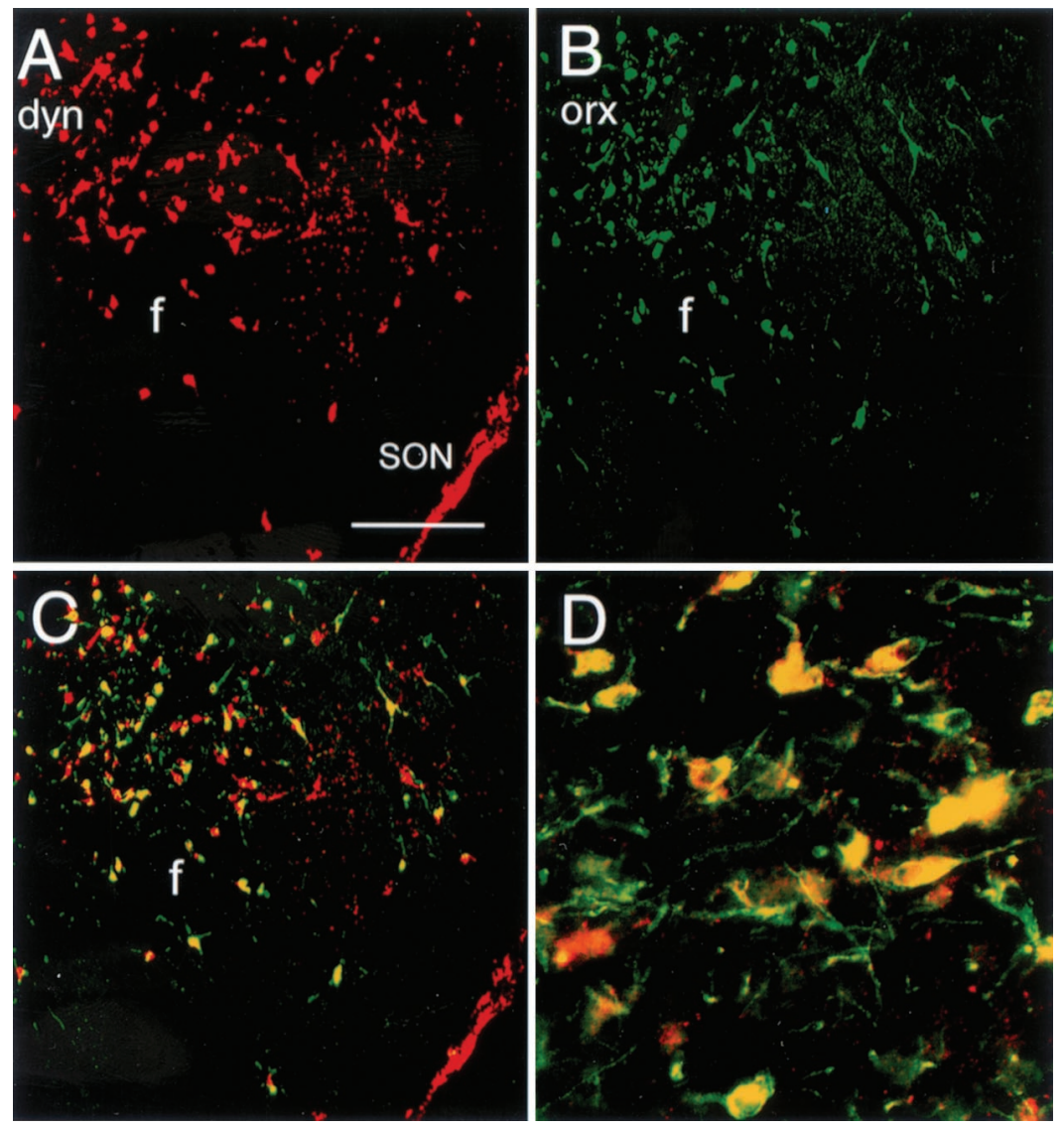

orexin neurons, dynorphin may play a role that is coordinated with that of orexin. Dynorphin levels in the hypothalamus increase markedly at night, when rats are mostly awake (Przewlocki et al., 1983). Similarly, Fos expression increases in orexin neurons at night (Scammell et al., 2000; Estabrooke et al., 2001), and CSF levels of orexin are also increased at night (Fujiki et al., 2001). Food deprivation increases prepro-orexin mRNA (Cai et al., 1999), whereas combined deprivation of food and water increases hypothalamic dynorphin levels (Przewlocki et al., 1983). Dynorphin fibers are found in most brain regions containing orexin fibers, including the monoaminergic nuclei such as the tuberomammillary nucleus, raphe nuclei, and locus coeruleus (Fallon and Leslie, 1986; Peyron et al., 1998; van den Pol, 1999), suggesting that dynorphin may be released at similar places and times as orexin.

Orexin knock-out mice have a modest reduction in food intake and a mild tendency toward obesity (Chemelli et al., 2001; Willie et al., 2001). Orexin/ataxin-3 mice have more severe obesity and hypophagia than orexin knock-out mice (Hara et al., 2001). These different phenotypes may be attributable to the different testing environments and background strains of the mice or because the orexin/ataxin-3 mice are normal at birth and may have fewer compensatory adaptations. However, another intriguing possibility is that the more severe abnormalities of the orexin/ataxin-3 mice are attributable to loss of other neurotransmitters in the orexin neurons that regulate feeding and metabolic activity. Consistent with this hypothesis, feeding is promoted by injections of dynorphin-A or dynorphin agonists either systemically or into hypothalamic regions where orexin terminals are abundant (Morley and Levine, 1981; Gosnell et al., 1986). The effects of dynorphin on body weight and metabolism are unknown; prodynorphin knock-out mice have been reported (Sharifi et al., 2001), but have not been tested for changes in feeding, metabolic activity, or energy balance.

Orexin and dynorphin may also have related effects on sleepwake regulation. Injections of orexin-A into the locus coeruleus increase wakefulness and decrease REM sleep (Bourgin et al., 2000). Although dynorphin is mainly a $\kappa$-opioid agonist, it also binds to the $\mu$-opioid receptor, and pontine injections of a $\mu$ receptor agonist also decrease REM sleep (Cronin et al., 1995).

Despite their coordinated actions, orexin and dynorphin may have paradoxically opposing electrophysiological effects. Orexin excites neurons in the locus coeruleus (Horvath et al., 1999; Ivanov and Aston-Jones, 2000), whereas dynorphin may inhibit these neurons via the $\mu$-opioid receptor (Beacham et al., 2000). Orexin increases intracellular calcium levels in dopaminergic neurons (Nakamura et al., 2000), presumably a sign of neuronal activation, whereas dynorphin inhibits firing of cultured dopaminergic neurons (Ronken et al., 1993). Orexin excites neurons in the dorsal raphe nucleus (Brown et al., 2001) and the tuberomammillary nucleus (Eriksson et al., 2000), but the effects of dynorphin on these neurons are unknown.

The perspective of our experiments and discussion has focused on dynorphin- $\mathrm{A}$, but the prodynorphin gene also produces dynorphin-B (also called rimorphin), leumorphin, $\alpha$ neoendorphin and $\beta$ neo-endorphin (Suda et al., 1983; James et al., 1984). These peptides are also $\kappa$ agonists and may augment the actions of dynorphin-A.

Our findings may have implications for understanding narcolepsy in humans. Many narcoleptics with cataplexy have extremely low concentrations of orexin-A in their CSF (Nishino et al., 2000), and postmortem studies show a loss of orexin mRNA and peptide in the hypothalamus as well (Peyron et al., 2000; 

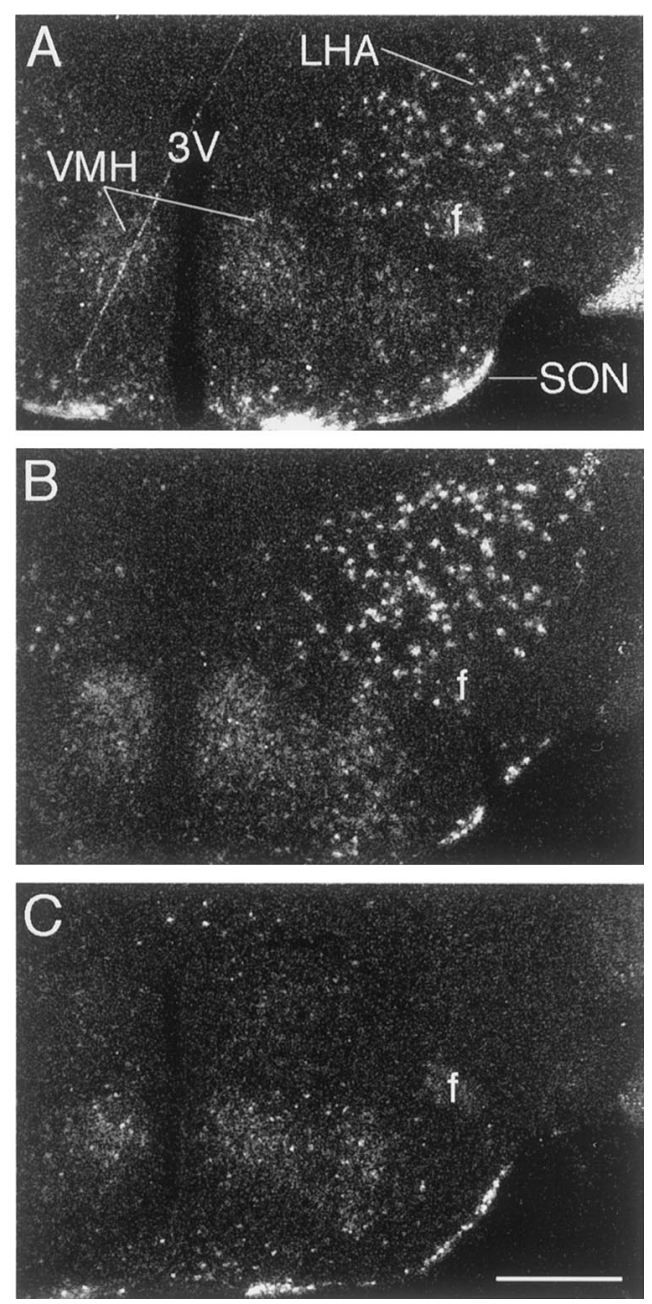

Figure 3. Dark-field photomicrographs showing silver grains corresponding to prodynorphin hybridization in wild-type mice $(A)$, orexin knock-out mice $(B)$, and orexin/ataxin-3 transgenic mice $(C)$, which have a selective loss of orexin neurons. Prodynorphin expression in the LHA is abundant in wild-type and orexin knock-out mice but completely absent in the orexin/ataxin-3 mice. Scale bar, $500 \mu \mathrm{m}$.

Thannickal et al., 2000). However, it is unknown whether orexin neurons are absent from the brains of narcoleptics or whether the neurons are simply failing to produce orexin mRNA and peptides. If orexin and dynorphin are colocalized in normal human brains, then the presence or absence of dynorphin could establish whether the orexin neurons, or just orexin expression, is lost in human narcolepsy.

The nearly complete colocalization of dynorphin with orexin in the LHA suggests that dynorphin may play an important role in the function of the orexin neurons. Orexin neurons may regulate sleep-wake behavior, feeding, and metabolic activity, and dynorphin may influence some of these behaviors. Dynorphin in the orexin neurons may also play other roles that have not yet been explored. Further research, including the development of transgenic mice in which the prodynorphin gene is disrupted only in the orexin neurons, is needed to help elucidate the role of dynorphin within the orexin cells.

\section{REFERENCES}

Beacham D, Silbert S, Stone L, Williams J, McCleskey E (2000) Dynorphin modulation of rat sensory and locus coeruleus neurons through the mu-opioid receptor. Soc Neurosci Abstr 26:823.6.
Bourgin P, Huitron-Resendiz S, Spier AD, Fabre V, Morte B, Criado JR, Sutcliffe JG, Henriksen SJ, de Lecea L (2000) Hypocretin-1 modulates rapid eye movement sleep through activation of locus coeruleus neurons. J Neurosci 20:7760-7765.

Brown RE, Sergeeva O, Eriksson KS, Haas HL (2001) Orexin A excites serotonergic neurons in the dorsal raphe nucleus of the rat. Neuropharmacology 40:457-459.

Cai XJ, Widdowson PS, Harrold J, Wilson S, Buckingham RE, Arch JR, Tadayyon M, Clapham JC, Wilding J, Williams G (1999) Hypothalamic orexin expression: modulation by blood glucose and feeding. Diabetes 48:2132-2137.

Chemelli RM, Willie JT, Sinton CM, Elmquist JK, Scammell T, Lee C, Richardson JA, Williams SC, Xiong Y, Kisanuki Y, Fitch TE, Nakazato M, Hammer RE, Saper CB, Yanagisawa M (1999) Narcolepsy in orexin knockout mice: molecular genetics of sleep regulation. Cell 98:437-451

Chemelli R, Willie J, Xiong Y, Yanagisawa M (2001) Metabolic Characterization of Orexin Knockout Mice. Sleep 24:A21-A22.

Civelli O, Douglass J, Goldstein A, Herbert E (1985) Sequence and expression of the rat prodynorphin gene. Proc Natl Acad Sci USA 82:4291-4295.

Cronin A, Keifer JC, Baghdoyan HA, Lydic R (1995) Opioid inhibition of rapid eye movement sleep by a specific mu receptor agonist. $\mathrm{Br} \mathrm{J}$ Anaesth 74:188-192.

Cutler DJ, Morris R, Evans ML, Leslie RA, Arch JR, Williams G (2001) Orexin-A immunoreactive neurons in the rat hypothalamus do not contain neuronal nitric oxide synthase (nNOS). Peptides 22:123-128.

Elias CF, Lee CE, Kelly JF, Ahima RS, Kuhar M, Saper CB, Elmquist JK (2001) Characterization of CART neurons in the rat and human hypothalamus. J Comp Neurol 432:1-19.

Eriksson K, Sergeeva O, Brown R, Haas H (2000) Orexin excites tuberomammillary neurons. International histamine symposium, Sendai, Japan, November.

Estabrooke IV, McCarthy MT, Ko E, Chou TC, Chemelli RM, Yanagisawa M, Saper CB, Scammell TE (2001) Fos expression in orexin neurons varies with behavioral state. J Neurosci 21:1656-1662.

Fallon JH, Leslie FM (1986) Distribution of dynorphin and enkephalin peptides in the rat brain. J Comp Neurol 249:293-336.

Fujiki N, Yoshida Y, Ripley B, Honda K, Mignot E, Nishino S (2001) Changes in CSF hypocretin-1 (orexin A) levels in rats across 24 hours and in response to food deprivation. NeuroReport 12:993-997.

Gosnell BA, Morley JE, Levine AS (1986) Opioid-induced feeding: localization of sensitive brain sites. Brain Res 369:177-184.

Griffond B, Deray A, Fellmann D, Ciofi P, Croix D, Bugnon C (1993) Colocalization of prolactin- and dynorphin-like substances in a neuronal population of the rat lateral hypothalamus. Neurosci Lett 156:91-95.

Hakansson M, de Lecea L, Sutcliffe JG, Yanagisawa M, Meister B (1999) Leptin receptor- and STAT3-immunoreactivities in hypocretin/orexin neurones of the lateral hypothalamus. J Neuroendocrinol 11:653-663.

Hara J, Beuckmann C, Nambu T, Willie J, Chemelli R, Sinton C, Sugiyama F, Yagami K, Goto K, Yanagisawa M, Sakurai T (2001) Genetic ablation of orexin neurons in mice causes a sleep disorder similar to human narcolepsy, hypophagia, and obesity. Neuron 30:345354.

Harlan RE, Scammell JG (1991) Absence of pituitary prolactin epitopes in immunoreactive prolactin of rat brain. J Histochem Cytochem 39:221-224.

Horvath TL, Peyron C, Diano S, Ivanov A, Aston-Jones G, Kilduff TS, van Den Pol AN (1999) Hypocretin (orexin) activation and synaptic innervation of the locus coeruleus noradrenergic system. J Comp Neurol 415:145-159.

Ivanov A, Aston-Jones G (2000) Hypocretin/orexin depolarizes and decreases potassium conductance in locus coeruleus neurons. NeuroReport 11:1755-1758.

James IF, Fischli W, Goldstein A (1984) Opioid receptor selectivity of dynorphin gene products. J Pharmacol Exp Ther 228:88-93.

Josefsen K, Buschard K, Sorensen LR, Wollike M, Ekman R, Birkenbach M (1998) Glucose stimulation of pancreatic beta-cell lines induces expression and secretion of dynorphin. Endocrinology 139:4329-4336.

Kerner JA, Standaert DG, Penney JB, Young AB, Landwehrmeyer GB (1998) Simultaneous isotopic and nonisotopic in situ hybridization histochemistry with cRNA probes. Brain Res Brain Res Protoc 3:22-32.

Lin L, Faraco J, Li R, Kadotani H, Rogers W, Lin X, Qiu X, de Jong PJ, Nishino S, Mignot E (1999) The sleep disorder canine narcolepsy is caused by a mutation in the hypocretin (orexin) receptor 2 gene. Cell 98:365-376.

Marcus J, Aschkenasi C, Lee C, Chemelli R, Saper C, Yanagisawa M, Elmquist JK (2001) Differential expression of orexin receptors 1 and 2 in the rat brain. J Comp Neurol 435:6-25.

Morley JE, Levine AS (1981) Dynorphin-(1-13) induces spontaneous feeding in rats. Life Sci 29:1901-1903.

Nakamura T, Uramura K, Nambu T, Yada T, Goto K, Yanagisawa M, 
Sakurai T (2000) Orexin-induced hyperlocomotion and stereotypy are mediated by the dopaminergic system. Brain Res 873:181-187.

Nishino S, Ripley B, Overeem S, Lammers GJ, Mignot E (2000) Hypocretin (orexin) deficiency in human narcolepsy. Lancet 355:39-40.

Peyron C, Tighe DK, van den Pol AN, de Lecea L, Heller HC, Sutcliffe JG, Kilduff TS (1998) Neurons containing hypocretin (orexin) project to multiple neuronal systems. J Neurosci 18:9996-10015.

Peyron C, Faraco J, Rogers W, Ripley B, Overeem S, Charnay Y, Nevsimalova S, Aldrich M, Reynolds D, Albin R, Li R, Hungs M, Pedrazzoli M, Padigaru M, Kucherlapati M, Fan J, Maki R, Lammers GJ, Bouras C, Kucherlapati R, Nishino S, Mignot E (2000) A mutation in a case of early onset narcolepsy and a generalized absence of hypocretin peptides in human narcoleptic brains. Nat Med 6:991-997.

Przewlocki R, Lason W, Konecka AM, Gramsch C, Herz A, Reid LD (1983) The opioid peptide dynorphin, circadian rhythms, and starvation. Science 219:71-73.

Risold PY, Griffond B, Kilduff TS, Sutcliffe JG, Fellmann D (1999) Preprohypocretin (orexin) and prolactin-like immunoreactivity are coexpressed by neurons of the rat lateral hypothalamic area. Neurosci Lett 259:153-156.

Ronken E, Van Muiswinkel FL, Mulder AH, Schoffelmeer AN (1993) Opioid receptor-mediated inhibition of evoked catecholamine release from cultured neurons of rat ventral mesencephalon and locus coeruleus. Eur J Pharmacol 230:349-355.

Sakurai T, Amemiya A, Ishii M, Matsuzaki I, Chemelli RM, Tanaka H, Williams SC, Richarson JA, Kozlowski GP, Wilson S, Arch JR, Buckingham RE, Haynes AC, Carr SA, Annan RS, McNulty DE, Liu WS,
Terrett JA, Elshourbagy NA, Bergsma DJ, Yanagisawa M (1998) Orexins and orexin receptors: a family of hypothalamic neuropeptides and $\mathrm{G}$ protein-coupled receptors that regulate feeding behavior. Cell 92:573-585.

Scammell TE, Estabrooke IV, McCarthy MT, Chemelli RM, Yanagisawa M, Miller MS, Saper CB (2000) Hypothalamic arousal regions are activated during modafinil-induced wakefulness. J Neurosci 20:8620-8628.

Sharifi N, Diehl N, Yaswen L, Brennan MB, Hochgeschwender U (2001) Generation of dynorphin knockout mice. Brain Res Mol Brain Res 86:70-75.

Simmons D, Arriza J, Swanso L (1989) A complete protocol for in situ hybridization of messenger RNAs in brain and other tissues with radiolabeled single-stranded RNA probes. J Histotechnol 12:169-181.

Suda M, Nakao K, Yoshimasa T, Ikeda Y, Sakamoto M, Yanaihara C, Numa S, Imura H (1983) Comparison of the action of putative endogenous kappa-agonists, leumorphin and rimorphin in vitro. Life Sci 33:275-278.

Thannickal TC, Moore RY, Nienhuis R, Ramanathan L, Gulyani S, Aldrich M, Cornford M, Siegel JM (2000) Reduced number of hypocretin neurons in human narcolepsy. Neuron 27:469-474.

van den Pol AN (1999) Hypothalamic hypocretin (orexin): robust innervation of the spinal cord. J Neurosci 19:3171-3182.

Willie JT, Chemelli RM, Sinton CM, Yanagisawa M (2001) To eat or to sleep? orexin in the regulation of feeding and wakefulness Annu Rev Neurosci 24:429-458. 